\title{
OBRZĘDY PRZYJĘCIA DO WSPÓLNOTY MNICHÓW WED $Ł U G$ CEREMONIAŁU TYNIECKIEGO Z XVIII WIEKU A WSKAZANIA ŚW. BENEDYKTA Z NURSJI
}

Streszczenie. Św. Benedykt z Nursji pozostawił w swojej regule wytyczne dotyczące przyjmowania braci i profesji mniszej. Od VIII wieku wytyczne te były wzbogacane licznymi rytuałami, modlitwami i gestami podkreślającymi znaczenie profesji monastycznej. Przykładem są obrzędy przewidziane przez XVIII-wieczny ceremoniał tyniecki obowiązujący w Kongregacji św. Krzyża w Polsce. Należą do nich obrzędy odprawiane przed przyjęciem do nowicjatu, obrzędy ślubów zakonnych, zarówno uroczystych, jak i prostych, oraz włączenie do pełnej komunii z braćmi profesami. Ważnym elementem profesji zakonnej było odczytanie dokumentu z przysięgą, podpisanie go znakiem krzyża i złożenie go na ołtarzu. Oznaką oddania się Bożej służbie było zaśpiewanie wersetu: „Podtrzymaj mnie według swojej obietnicy, bym żył; nie zawiedź mojej nadziei!” (Ps 119 [118]: 116), podczas którego towarzyszyły gesty wskazujące na pełne oddanie neoprofesa Bogu. Nieznanym obrzędem według reguły benedyktyńskiej było pełne włączenie do wspólnoty mniszej dopiero na trzeci dzień po ślubach uroczystych. Ceremoniał tyniecki jest cennym źródłem poznania liturgii benedyktynów w Polsce w XVIII i na początku XIX w.

Słowa kluczowe: liturgia religijna; zawód zakonny; Reguła św. Benedykta.

Abstract. Abstract. Rites of Reception into a Community of Monks according to the Tyniec Ceremonial of the $18^{\text {th }}$ Century and the Instructions of St. Benedict of Nursia. In his rule, St. Benedict of Nursia left guidelines for the admission of brothers 
and the profession of monks. Since the $8^{\text {th }}$ century, these guidelines have been enriched with numerous rituals, prayers and gestures illustrating the meaning of the monastic profession. An example of this are the rites set out in the $18^{\text {th }}$-century Tyniec Ceremonial used by the Congregation of the Holy Cross in Poland. These include rites celebrated for admission to the novitiate; rites for religious vows, both solemn and simple; and inclusion into full communion with the professed brothers. An important element of the monastic profession was the reading of the document with an oath, signing it with the sign of the cross, and placing it on the altar. A sign of dedication to the service of God was the singing of the verse "Sustain me by your promise that I may live; do not disappoint me in my hope!” (Ps. 119[118]:116) accompanied by gestures showing the complete dedication of the newly professed to God. An unknown rite of the Benedictine Rule was that of full inclusion into the community three days after the vows were made. The Tyniec Ceremonial is a valuable source for learning about the liturgy of the Benedictines in Poland in the 18 th and early $19^{\text {th }}$ centuries.

Keywords: religious liturgy; monastic profession; Rule of Saint Benedict.

Wspólnoty benedyktyńskie, zgodnie ze wskazaniem św. Benedykta z Nursji, że „Nic nie może być ważniejsze od Służby Bożej”', od samego początku były centrami życia liturgicznego w świecie chrześcijańskim. Poprzez celebrację liturgii oraz troskę o śpiew liturgiczny przyczyniły się one do rozwoju liturgii $\mathrm{w}$ tradycji zachodniej. Wszystkie te inspiracje czerpały z prawodawstwa zakonnego, jakim była reguła św. Benedykta, która uwzględniała ówczesne rzymskie zwyczaje liturgiczne ${ }^{2}$. Dopiero od VIII wieku powstawały liczne obrzędy liturgiczne na kanwie wskazań św. Benedykta, które od X wieku spisywano w tzw. zwyczajnikach (consuetudines) ${ }^{3}$.

Pośród różnych celebracji sprawowanych w tradycji monastycznej na uwagę zasługują te, które były związane z przyjęciem do życia zakonnego oraz złożeniem profesji mniszej. Jakkolwiek istotne wskazania dotyczące tych kwestii można odnaleźć w regule św. Benedykta w rozdziale 58: O zasadach przyjmowania braci, to jednak w ciągu wieków w oparciu

1 Św. Benedykt z Nursji, Reguła, Tyniec 1994, 43, 3 (dalej: Reguła).

2 M. Puzicha, Kommentar zur Benediktusregel, St. Ottilien 2002, s. 205; A de Vogüé, La comunità ordinamento e spiritualità, Praglia 1991, s. 299-301; B. Rollin, Jak żyć dzisiaj Regułą św. Benedykta. Komentarz do Reguły, Kraków 2005, s. 137-139.

3 J. W. Boguniowski, Rozwój historyczny ksiag liturgii rzymskiej do Soboru Trydenckiego i ich recepcja w Polsce, Kraków 2001, s. 151-152. 
o te wytyczne powstały własne zwyczaje ${ }^{4}$. Na ziemiach polskich przykładem jest ceremoniał tyniecki z XVIII wieku, w którym utrwalono zwyczaje obowiązujące w Kongregacji Benedyktynów św. Krzyża w Polsce utworzonej w 1711 roku. Został on wydrukowany w 1777 roku i zastąpił używany do tego czasu ceremoniał kongregacji bawarskiej ${ }^{5}$.

Uwzględniając własne zwyczaje Kongregacji Benedyktynów św. Krzyża w Polsce utrwalone w ceremoniale tynieckim z XVIII wieku, interesującym zagadnieniem badawczym pozostaje wskazanie, na ile są one odzwierciedleniem wytycznych reguły św. Benedykta i jakie obrzędy zostały dodane, aby wyraźniej poprzez celebracje ukazać znaczenie wprowadzenia nowego zakonnika do życia monastycznego. Celebracje te zostały umieszczone w części VI (De caeremoniis monasticis) w rozdziałach od I do VI.

\section{OBRZĘD PRZYJĘCIA KANDYDATÓW}

Święty Benedykt przy przyjmowaniu kandydata do zakonu wymagał, aby dokładnie zbadać motyw, czy pochodzi od Boga (por. $1 \mathrm{~J} 4,1$ ), oraz czy potrafi być cierpliwy i znosić przykrości i utrudnienia ${ }^{6}$. Czas próby, o którym wspomina św. Benedykt, zmieniał się w historii wraz z rozwojem życia zakonnego ${ }^{7}$. Rozporządzenia dotyczące przyjmowania nowych braci zostały przedłożone $\mathrm{w}$ ceremoniale tynieckim w rozdziale I (Modus suscipiendi Candidatum in Sacrum Ordinem nostrum). Na począt$\mathrm{ku}$ przede wszystkim badano, czy u podstaw motywacji jest pragnienie służenia Jezusowi, czy też może wygodny styl życia, co zostało wyrażone w grze słów: ...quia talis veniret magis propter esum, quam propter Jesum. Jak zaznaczono, powołanie powinno być dobrowolne i na chwałę Bożą

${ }^{4}$ B. Happle, Die Profeßordnung des 58. Kapitels der Benediktinerregel, BM 31 (1955), s. 9.

${ }_{5}$ M. Kanior, Polska kongregacja benedyktyńska św. Krzyża 1709-1864, Kraków 2000, s. 166, 277; P. Sczaniecki, Benedyktyni, w: Zakony benedyktyńskie w Polsce. Krótka historia, Tyniec 1981, s. 57; K. Estreicher, Bibliografia Polska, t. 20, Kraków 1905, s. 175.

6 Reguła 58, 1-4.

7 M. Rothenhäusler, Unter dem Geheimnis des Kreuzes. Die klösterliche Profess bei Kassian, BM 5 (1923), s. 93-94. 
pod natchnieniem Ducha Świętego ${ }^{8}$. Życie monastyczne od początku było bowiem szczególnym darem Ducha Świętego, a mnicha określano jako kogoś, kto jest Nim napełniony i w pełni Go posiada ( $\pi v \varepsilon v \mu \alpha \tau o \varphi o ́ \rho o \varsigma){ }^{9}$.

Badanie motywów wstąpienia aspiranta, według ceremoniału, przyjmowało formę dialogu pomiędzy kandydatem a wspólnotą. Przewidywano, że najpierw aspirant pisał prośbę, wyrażając gorące pragnienie, aby został przyjęty do Kongregacji. Tę prośbę czytano pośród wszystkich zgromadzonych zakonników w kapitularzu. Jeżeli prośba została przyjęta, wówczas kandydat był zaproszony do kapitularza, gdzie zapytany przez przełożonego, o co prosi, odpowiadał, że prosi o miłosierdzie od Boga i od zgromadzonych braci. Wówczas na pytanie: dlaczego o to prosi odpowiadał, że pragnie podobać się Bogu i Ojcom we wspólnocie oraz, że chce zbawić własną duszę ${ }^{10}$.

O istocie życia zakonnego mówił przełożony w dłuższej przemowie. Na początku zwracał on uwage, że jeżeli aspirant przyjmie na siebie jarzmo reguły, wówczas koniecznie będzie musiał wypełnić słowa Zbawiciela: „Jeśli ktoś chce iść za Mną, niech się zaprze samego siebie, niech co dnia bierze krzyż swój i niech Mnie naśladuje" (Łk 9,23). Skoro kandydat jest gotowy rzeczywiście podjąć obowiązki zakonne będzie to oznaczało, że zrezygnuje całkowicie ze swojej woli, porzuci dotychczasowe skłonności, namiętności i przepych światowy. Ponadto życie zakonne będzie wymagało, że kandydat ze względu na Chrystusa będzie znosił zniewagi, niesprawiedliwość, pokusy, trudności, prześladowania i uciemiężenia. Jeżeli natomiast kandydat nie byłby gotowy podjąć tych wyrzeczeń, to lepiej, aby nie wchodził na drogę życia monastycznego. Taka droga przedstawiana była jako stroma i wąska, co podkreślał św. Benedykt ${ }^{11}$. Otuchą jednak było wezwanie Jezusa: „Weźcie moje jarzmo na siebie i uczcie się ode Mnie, bo jestem cichy i pokorny sercem, a znajdziecie ukojenie dla dusz waszych. Albowiem jarzmo moje jest słodkie, a moje brzemię lekkie" (Mt 11,29-30). Wejście jednak na tę drogę spowoduje, że z rozszerzonym sercem i z niewysłowioną radością pobiegnie drogą Bożych

\footnotetext{
8 Ceremoniał, s. 1-2.

9 Y. Congar, Wierzę w Ducha Świętego, t. I, Warszawa 1995, s. 117-119.

10 Ceremoniał, s. 2.

11 Reguła 5, 11.
} 
przykazań, co wyraźnie przywołuje tu myśl św. Benedykta ${ }^{12}$. Dopiero gdy kandydat rzeczywiście zdecyduje się na poszukiwanie Boga wówczas bramy świętego zakonu stanął dla niego otworem ${ }^{13}$. Poszukiwanie Boga w życiu monastycznym było bowiem od początku podstawą całego życia monastycznego ${ }^{14}$.

Podczas dalszych etapów formacji przewidziano, aby kandydat przez 15 dni odbywał próbę, uczestnicząc w tym czasie wraz z braćmi w modlitwie chórowej i w refektarzu. Po upływie tego czasu miał być ponownie zapytany o motyw swego wstąpienia do zakonu. Jeżeli odpowiedź była pozytywna wówczas mistrz nowicjatu prowadził go do balwierza, aby ogolił jego brodę i głowę według norm zakonnych ${ }^{15}$. Przyjęcie tonsury było bowiem wyrazem oddania Chrystusowi ${ }^{16}$.

Znakiem przyjęcia do nowicjatu było przyjęcie habitu. W pierwszych wiekach chrześcijaństwa samo przyjęcie habitu zakonnego było już znakiem przynależności do wspólnoty i podjęciem zobowiązań wynikających z poświęcenia Bogu ${ }^{17}$. Celebracje obłóczyn zostały przedstawione $\mathrm{w}$ rozdziale II (Modus induendi Candidatum in S. Ordinem nostrum susceptum) i były sprawowane przed tercją w chórze lub kapitularzu, ale nie mogły się one odbyć w kościele. Kandydat w szatach świeckich ubrany na czarno i z kapeluszem na głowie klękał przed przełożonym. Celebrans po wezwaniu V. Adiutorium nostrum in Nomine Domini. / R. Qui fecit caelum, et terram (por. Ps 121 [120],2) dodawał wersety zaczerpnięte z Księgi Psalmów oraz trzy modlitwy, w których przełożony prosił o szczególne dary dla nowicjusza. W pierwszej z nich: Deus, qui nos, a saeculi vanitate conversos... prosił, aby kandydat po wyrzeczeniu się świata zachował postanowienia w życiu zakonnym i je wypełniał. Słowami modlitwy: Domine Jesu Christe Dux, et fortitudo nostra... prosił za tym, którego Bóg oddzielił od ludzi tego świata i od nieczystości ziemskiej, aby Pan wlał w niego poznanie świętości i łaskę, dzięki której zostanie dla Niego zacho-

12 Reguła, Prolog 48-49.

13 Ceremoniał, s. 2-7.

14 Reguła 58, 7.

15 Ceremoniał, s. 7-8.

16 Cz. Krakowiak, Tonsura, EK 19, kol. 891.

17 M. Rothenhäusler, Die Anfänge der klösterlichen Profess, BM 4 (1922), s. 27-28; A.G. Martimort, Handbuch der Liturgiewissenschaft, t. II, Freiburg im Breisgau 1965, s. 196. 
wany. W ostatniej modlitwie: Deus qui beatissimum Patrem nostrum Benedictum... przyzywał wstawiennictwa Zakonodawcy, aby wspomógł kandydata, by służył pod jego prawem zachowując wytrwałość aż do końca ${ }^{18}$. O tej wytrwałości pisał św. Benedykt w kontekście pokory ${ }^{19}$.

Przed pobłogosławieniem habitu przyzywano Ducha Świętego śpiewając hymn: Veni, creator Spiritus, klęcząc podczas pierwszej strofy. Hymn ten jest znany w liturgii już od X w. i towarzyszył podczas ważnych wydarzeń w życiu wspólnoty ${ }^{20}$. Błogosławiąc szkaplerz z kapturem, przełożony odmawiał modlitwę: Deus aeternorum bonorum fidelissime promissor... Wzywając Boga, który swoim wiernym obiecał szatę zbawienia i odzienie radości, przełożony prosił, aby pobłogosławił szaty zakonne oznaczające pokorę serca, wzgardę światem i wyrzeczenie. Prosił, aby przyjmujący habit został kiedyś odziany w szaty błogosławionej nieśmiertelności. Natomiast po pokropieniu szat wodą pobłogosławioną przełożony zdejmował z kandydata świeckie szaty i wypowiadał formułę: Exuat te Dominus veterem hominem cum actibus suis, a zakładając szaty zakonne mówił: Induat te Dominus novum hominem, qui secundum Deum creatus est, in justitia, \& sanctitate veritatis ${ }^{21}$. Formuły te w liturgii zachodniej były znane już od XII wieku².

Nowo obłóczonemu nowicjuszowi przełożony przekazywał księgę reguły św. Benedykta ze słowami: Ecce Lex, sub qua militare vis, vide, ut non solum auditor, verumetiam factor illius esse possis ${ }^{23}$. Po przekazaniu szat celebrans odmawiał dwie modlitwy. W pierwszej z nich: Dignare Domine famulo tuo N. renuntianti saecularibus pompis gratiam tuam tribuere... modlono się o łaskę dla kandydata, aby ten, który przyjął tonsurę i habit zakonny, mógł zachować ducha wytrwania w dobrym i w wolności od świata oraz pokus światowych. W drugiej modlitwie: Dignare Domine famulo tuo $N$. renuntianti saecularibus pompis gratiae tuae januas aperiri... celebrans prosił dla kandydata, który wyrzeka się światowego przepychu i gardzi szatanem, aby nieprzyjaciel nie triumfował nad nim, ale nałożył

18 Ceremoniał, s. 8-11.

19 Reguła 7, 36.

20 M. Straszewicz, Veni, creator Spiritus, EK 20, kol. 43.

${ }^{21}$ Ceremoniał, s. 12.

22 Martimort, Handbuch der Liturgiewissenschaft, t. II, s. 201.

23 Ceremoniał, s. 13. 
na niego pancerz wiary ${ }^{24}$. W ten sposób mnich miał stać się żołnierzem, a metafora ta była znana w tekstach św. Pawła ${ }^{25}$.

Znakiem zmienionego życia było nadanie nowego imienia. Na zapytanie o imię, opat odpowiadał, że: Nequaquam vocaberis amplius NN. sed NN erit nomen tuum. Wówczas nowicjusz po ucałowaniu ręki prałata powracał do chóru i uczestniczył we Mszy św. konwentualnej, podczas której przyjmował Komunię św. ${ }^{26}$ Św. Benedykt przewidywał, że nowicjusz powinien wówczas zamieszkać w celi nowicjuszy, gdzie będzie rozmyślał, a także jadał i sypiał. Miał mieć również przydzielonego starszego mnicha, który obserwowałby nowicjusza, czy rzeczywiście szuka Boga, czy jest gorliwy i czy cierpliwie znosi trudy ${ }^{27}$.

\section{CELEBRACJE PRZED PRZYJĘCIEM DO PROFESJI MNISZEJ}

Znakiem złączenia kandydata ze wspólnotą jest profesja zakonna, którą składał po czasie próby. Zanim jednak aspirant został do niej dopuszczony, wspólnota jeszcze raz musiała poznać jego zamiar. Według ceremoniału tynieckiego to poznanie miało również charakter celebracji i zostało przedstawione w rozdziale III (Modus praeparandi, ac suscipiendi Novitium ad futuram sacram Professionem). W rubrykach przypomniano zasadę obowiązującą według reguły, że przez pierwsze dwa miesiące należało odczytać nowicjuszowi regułę ${ }^{28}$. Wówczas przed zgromadzoną kapitułą zastanawiano się nad gotowością kandydata do wytrwania we wspólnocie i omawiano ewentualne jego wady. Jeśli kapituła wypowiedziała się pozytywnie, to zapraszano kandydata na kapitułę. Opat wówczas zwracał się do kandydata przypominając mu, że ma wolny wybór, albo pozostać we wspólnocie, albo z niej odejśćc ${ }^{29}$. O tym wolnym wyborze wspomina również św. Benedykt w swojej regule ${ }^{30}$. Wówczas kandydat, jeżeli

\footnotetext{
${ }^{24}$ Ceremoniał, s. 13-14.

25 A. de Vogüé, Jak formować do stałości? „Cenobium” 23 (2016), s. 79.

${ }^{26}$ Ceremonial, s. $14-15$.

27 Reguła 58, 5-8.

${ }^{28}$ Reguła 58, 9.

${ }^{29}$ Ceremoniał, s. $15-16$.

30 Reguła 58, 10.
} 
postanowił zostać, wyrażał to słowami, że z Bożą pomocą pragnie trwać w świętym zakonie do końca życia ${ }^{31}$.

Zgodnie $\mathrm{z}$ regułą św. Benedykta kolejne badanie kandydata miało miejsce po kolejnych sześciu miesiącach, kiedy ćwiczono go w cierpliwości. Następnie po czterech miesiącach ponownie odczytywano regułę nowicjuszowi, co wieńczyło jego roczną próbę ${ }^{32}$. W celu dopuszczenia kandydata do profesji - zgodnie z ceremoniałem tynieckim - zwoływano kapitułę, podczas której kandydat prosił braci o przyjęcie. Opat w odpowiedzi upominał kandydata, że jego prośba o trwanie we wspólnocie dotyczy wierności regule oraz konstytucjom Kongregacji św. Krzyża. Jeżeli kapituła zdecydowała o przyjęciu kandydata, wówczas opat wskazywał $z$ jednej strony na habit mniszy, a $z$ drugiej na szaty świeckie, aby kandydat dokonał wyboru ${ }^{33}$. Zwyczaj ten przywołuje obraz Księgi Psalmów, kiedy wspomniano o dwóch drogach życia ${ }^{34}$. Po wyrażeniu pragnienia przez kandydata, że pragnie on żyć i umrzeć nosząc habit św. Benedykta opat wyznaczał dzień złożenia profesji, polecał, aby kandydat przygotował się do niej przez ośmiodniowe rekolekcje, przystąpił do sakramentu pokuty, a także odmawiał modlitwy: koronkę lub różaniec, psalmy pokutne lub gradualne, a także oficjum za zmarłych ${ }^{35}$. Św. Benedykt w regule zastrzegał bowiem, aby kandydat został przyjęty do wspólnoty dopiero po dojrzałej rozwadze i gdy będzie on przestrzegał wszystkich poleceńn ${ }^{36}$.

\section{OBRZĘDY PROFESJI UROCZYSTEJ}

Zgodnie $\mathrm{z}$ tradycją św. Benedykta kandydat do życia zakonnego składał profesję w oratorium wobec całej zgromadzonej wspólnoty. Zakonnik składał śluby „przed Bogiem i Jego Świętymi, żeby wiedział, że jeśli kiedykolwiek inaczej postąpi, zostanie potępiony przez Tego, z któ-

31 Ceremoniał, s. 16.

${ }^{32}$ Reguła, 58, 11-13.

33 Ceremoniał, s. 16-19.

${ }^{34}$ H.-W. Jüngling, Księga Psalmów, w: W.R. Farmer (red.), Międzynarodowy komentarz do Pisma Świętego, Warszawa 2001, s. 696.

35 Ceremoniał, s. 19.

36 Reguła 58, 14-16. 
rego szydzi”37. Ta forma obejmująca uroczyste zobowiązanie do podjęcia zakonnego stylu życia, określana jako professio znana była dopiero od VIII wieku. ${ }^{38}$

W ceremoniale tynieckim zamieszczono dwie formy profesji: uroczystej, składanej przez mnichów i prostej, którą składali bracia konwer$\mathrm{si}^{39}$. Celebracje profesji uroczystej zostały zapisane w rozdziale IV (Modus solemniter Profitendi). Profesja uroczysta była składana podczas Mszy św., o czym wyraźnie nie wspominał św. Benedykt. Mszę św. należało sprawować według formularza mszalnego $\mathrm{z}$ danego dnia liturgicznego, nie mogła być wówczas sprawowana uroczysta msza wotywna co zostało zabronione przez Kongregację Obrzędów 24 lipca $1683 \mathrm{r}^{40}$

Obrzęd ślubów zakonnych rozpoczynał się po okadzeniu darów ofiarnych przed lavabo. Jeżeli opat nie sprawował Mszy św., to podczas offertorium zakładał szaty liturgiczne, a ubrany w kapę udawał się do ołtarza. Wówczas kapłan sprawujący Mszę św. przechodził na stronę epistoły i posługiwał opatowi. Do ołtarza nowicjusza prowadził magister nowicjatu wraz ze swoim pomocnikiem. Opat śpiewem poszczególnych fraz wersetu: Venite, filii; audite me: timorem Domini (Ps 34 [33], 12), zapraszał kandydatów do złożenia profesji. Wspólnota za każdym razem odpowiadała, śpiewając kolejne wersety, zachęcając do błogosławienia Pana w każdym czasie, aby chlubić się w Panu, wywyższać Jego imię, gdyż On wysłuchał tego, który go szukał i uwolnił od wszelkiej trwogi (por. Ps $34[33], 2-6)^{41}$. Psalm ten w tradycji biblijnej był szczególnym pouczeniem o dobroci Boga i bojaźni Bożej ${ }^{42}$.

Istotnym momentem podczas profesji było odczytanie własnoręcznie napisanej roty ślubowania ${ }^{43}$. W rubrykach ceremoniału zaznaczono, że w tym czasie nie powinno otwierać się drzwiczek tabernakulum, co

37 Reguła 58, 17-18.

38 B. Nadolski, Liturgika, t. III, Poznań 1992, s. 230.

39 Profesja prosta braci konwersów nie była zrównana w skutkach z profesją uroczystą mnichów, dlatego jej przedstawienie wykracza poza ramy tego opracowania.

${ }^{40}$ Ceremoniał, s. 21.

41 Ceremoniał, s. 22-24.

${ }^{42}$ H.-W. Jüngling, Księga Psalmów, w: W.R. Farmer (red.), Międzynarodowy komentarz do Pisma Świętego, Warszawa 2001, s. 722.

${ }^{43}$ B. Happle, Die Profeßordnung des 58. Kapitels der Benediktinerregel, BM 31 (1955), s. 13. 
wydaje się, że mogło mieć miejsce w tym czasie. Według przewidzianej formuły nowicjusz przysięgał stałość, zmianę obyczajów i posłuszeństwo zgodnie $\mathrm{z}$ regułą św. Benedykta, przed Bogiem i wszystkimi świętymi, których relikwie znajdowały się $\mathrm{w}$ danym monsterze ${ }^{44}$. Po odczytaniu dokumentu nowicjusz podchodził do przełożonego, klękał przed nim, kładł kartę na gremiale przykrywającym jego kolanach, na której neoprofes kreślił znak krzyża. Ta forma dokładnie odpowiada wskazaniom św. Benedykta ${ }^{45}$. Te trzy śluby życia monastycznego porównywano do drzewa: stałość postrzegana była jako korzeń, nawrócenie obyczajów jako pień, gdzie poszczególne pierścienie tego pnia miały wskazywać na roczny wzrost w życiu duchowym, a posłuszeństwo koroną, która wznosi się do nieba ${ }^{46}$. Szczególnie stałość była traktowana jako fundament zachowania wszystkich pozostałych ślubów ${ }^{47}$. Ponadto należy podkreślić, że śluby mnisze - uroczyste - nie przewidują formuły „klasycznych" ślubów zakonnych, czyli rad ewangelicznych: czystości, ubóstwa i posłuszeństwa, które bardziej podkreślają indywidualny i ascetyczny ich charakter ${ }^{48}$.

Po podpisaniu karty neoprofes podchodził do ołtarza i kładł ją po stronie epistoły. Następnie klękał u stopni ołtarza, a opat po wersecie: V. Sit nomen Domini benedictum. / R. Ex hoc nunc, et usque in saeculum (Ps 113 [112],2). / V. Adjutorum nostrum... odmawiał modlitwę: Fratres charissimi... prosząc, aby to, co ów brat przyrzekł ustami, szczęśliwie wypełnił w czynach ${ }^{49}$. Według reguły benedyktyńskiej wyrazem złożonej profesji był śpiew wersetu: „Przyjmij mnie, Panie, według Twej obietnicy, a żyć będę. I nie zawiedź nadziei mojej" (Ps 119 [118],116 ), który trzykrotnie powtarzała wspólnota dodając za ostatnim razem Chwała Ojcu ${ }^{50}$. Dopowiedzeniem w ceremoniale były utrwalone w ciągu wieków gesty

${ }^{44}$ Ceremonial, s. 24-25.

45 Reguła, 58, 19-20

${ }^{46}$ B. Happle, Die Profeßordnung des 58. Kapitels der Benediktinerregel, BM 31 (1955), s. 104.

${ }^{47} \mathrm{~W}$ regule św. Benedykta nie występuje określenie stałość miejsca (stabilitas loci). Pojęcie to jest bardziej cnotą niż kategorią praktyczną albo prawną; J. Leclerq, Pochwała stałości, „Cenobium” 23 (2016), s. 24.

${ }^{48}$ W. Zatorski, Stałość w „Regule” św. Benedykta, „Cenobium” 23 (2016), s. 44.

49 Ceremoniał, s. 26.

50 Reguła 58, 21-22. 
towarzyszące podczas śpiewu tego wersetu: początkowo neoprofes stojąc śpiewał z wzniesionymi rękami pierwszą część, po czym łączył ręce na piersiach i kontynuował w postawie klęczącej, a na końcu całował ziemię. Po trzykrotnym odśpiewaniu, za każdym razem coraz wyżej, powtórzeniu przez chór, i dodaniu doksologii... śpiewano werset: Suscepimus Deus misericordiam tuam in medio templi tui (Ps 48 [47],10) wraz z Gloria Patri ${ }^{51}$. Sam śpiew doksologii Gloria Patri wskazuje tu, że profesja składana jest ku czci całej Trójcy Świętej ${ }^{52}$.

W regule św. Benedykta zapisano, że nowy brat powinien rzucić się każdemu do stóp braci prosząc o modlitwę ${ }^{53}$. Wyrazem tej prośby był fakt, że nad klęczącym neoprofesem opat odmawiał pięć modlitw. W pierwszej z nich: Omnipotens sempiterne Deus... opat dziękował, że kandydat zechciał przyjąć na siebie jarzmo reguły (por. Mt 11,29-30) i prosił, aby $\mathrm{w}$ dniu ostatecznym został postawiony po prawej stronie (por. Mt 25,34) i cieszył się kiedyś z obietnicy swego oddania. W modlitwie: Deus indulgentiarum Pater... prosił Boga, który potrafi w cudowny sposób zmieniać zło w dobro, aby skoro kandydat zmienia się od strony zewnętrznej po przyjęciu habitu, tak duchowej przemiany dokonał w nim Duch Święty. W trzeciej modlitwie: Deus, qui per Coaeternum Filium tuum cuncta creasti... prosił, aby Bóg spojrzał na sługę, który wyrzeka się świata i chce w ten sposób porzucić dawnego człowieka i przyoblec człowieka nowego, stworzonego według Boga (por. Ef 4, 22-24). W anamnezie czwartej modlitwy: Domine Iesu Christe, qui es via... przywoływano Chrystusa, który jest drogą do Ojca, aby prowadził swego sługę drogą dyscypliny zakonnej i zechciał usłyszeć słowa: „A kto by chciał Mi służyć, niech idzie za Mną” (J 12,26). W ostatniej modlitwie: Sancte Spiritus... proszono, aby udzielił on kandydatowi mocy i zapału pobożności. Przywołując wstawiennictwa św. Benedykta prosił, aby doznał on od niego pomocy, a ugruntowany w prawdziwej pokorze, posłuszeństwie i w braterskiej miłości, otrzymał łaskę wytrwania ${ }^{54}$.

51 Ceremoniał, s. 26.

52 B. Happle, Die Profeßordnung des 58. Kapitels der Benediktinerregel, BM 31 (1955), s. 107.

${ }^{53}$ Reguła, 58, 23-25.

54 Ceremonial, s. 27-31. 
Opat po zakończeniu modlitw błogosławił szaty mnisze. Po wezwaniu V. Dominus vobiscum. / R. Et cum Spiritu tuo odmawiał trzy modlitwy. W modlitwie Domine Iesu Christe... opat dziękował, że Chrystus poprzez wcielenie zechciał przyjąć szatę śmiertelną człowieka. Prosił, aby Pan pobłogosławił i uświęcił szaty, które święci ojcowie chcieli nosić jako znak niewinności, pokory i wyrzeczenia się świata. W drugiej modlitwie: Deus aeternorum bonorum fidelissime promissor... prosił o pobłogosławienie szat, które oznaczają pokorę serca i wzgardę świata, aby noszący je kiedyś został przyodziany w nieśmiertelność. W ostatniej modlitwie: Domine Deus bonarum virtutum dator... opat prosił o pobłogosławienie szat, które są znakiem posłuszeństwa ${ }^{55}$.

Znakiem przynależności zakonnej była kukulla, którą w tradycji określano jako szata krzyża ${ }^{56}$. Według ceremoniału po pokropieniu i okadzeniu szat neoprofes przystępował do stopni ołtarza i wszyscy klękali śpiewając hymn do Ducha Świętego. Po pierwszej zwrotce opat zasiadał na faldistorium i zdejmował z neoprofesa koszulę i płaszcz wypowiadając znaną formułę z obłóczyn: Exuat te Dominus..., a podczas zakładania szkaplerza: Induat te Dominus... Zakładając natomiast kukullę dodawał: Accipe hoc indumentum salutare, quod Sanctus Pater Benedictus illaesum custodivit, ut per eiusdem imitationem, ipsius caetui aggregatus, ante Tribunal Christi valeas perenniter gaudere. Per eundem Christum Dominum nostrum. Amen. Podając regułę i konstytucje Kongregacji, podobnie jak podczas obłóczyn wypowiadał słowa: Ecce Lex... ${ }^{57}$

Opat upraszał nad neoprofesem szczególnych łask odmawiając Modlitwę Pańską poprzedzoną wezwaniem Kyrie eleison, po której odmawiał wersety zaczerpnięte z Księgi Psalmów. Za neoprofesa opat odmawiał następnie trzy modlitwy. W modlitwie Deus misericors, Deus clemens... opat prosił, aby Bóg chronił go od więzów i pragnień światowych. Podobnie w drugiej modlitwie Deus, qui beatissimum Patrem nostrum Benedictum... wskazując na św. Benedykta, który pośród burz światowych zechciał służyć tylko Bogu prosił dla neoprofesa o stałość w wytrwaniu

55 Ceremoniał, s. 31-33.

56 O. Casel, Mönchtum und Pneuma, w: P. Krüger, J. Tyciak (Hrsg.), Morgenländisches Christentum. Wege zu einer ökumenischen Theologie, Paderborn 1940/44, s. 231.

57 Ceremoniał, s. 33-34. 
i zwycięstwo aż do końca ${ }^{58}$. Stałość bowiem oznacza wytrwałość prowadzącą do pokoju w obliczu różnych przeciwności i pokus ${ }^{59}$. W ostatniej modlitwie: Praesta Domine... dla sługi, który zrywa z przepychem światowym i lekceważąc szatana, ucieka się pod opiekę Chrystusa, prosił, aby Pan otworzył bramy Jego łaski, tak, aby nie triumfował nad nim wróg, a wzmocniony pancerzem wiary cieszył się pokonaniem wszelkich niebezpieczeństw i pokus diabelskich ${ }^{60}$. Zwłaszcza motyw pancerza wiary nawiązuje tu do listu św. Pawła do Efezjan i zachęty do walki duchowej (por. Ef 6,14-17) ${ }^{61}$.

Opat i wszyscy mnisi składali neoprofesowi znak pokoju. W tym czasie klęczał on na poduszce pośrodku chóru. Po przekazaniu znaku pokoju neoprofes kładł się na prawym boku, twarz zasłaniał kapturem - ręce i nogi kukullą, a następnie przykrywano go całunem pośmiertnym. Wokół niego stawiano cztery świeczniki z zapalonymi świecami ustawionymi na kształt krzyża, uderzano w dzwony jak zazwyczaj, gdy oznajmiano o śmierci zakonnika. Znak prostracji był wyrazem nie tylko oddania Bogu, ale również wspólnocie ${ }^{62}$. Tak okryty neoprofes pozostawał w postawie leżącej aż do Komunii św. celebransa, po której diakon podnosząc całun pośmiertny mówił: Surge qui dormis \& exurge a mortuis, \& illuminabit te Christus - Zbudź się, o śpiacy, i powstań z martwych, a zajaśnieje ci Chrystus (Ef 5,14). Neoprofes wstawał i jako pierwszy przystępował do Komunii św. ${ }^{63}$ Zwyczaj założenia szat zakonnych już od samego początku nawiązywał do śmierci Chrystusa, która miała prowadzić do zmartwychwstania wraz z $\mathrm{Nim}^{64}$.

Według ceremoniału tynieckiego z XVIII w. samo złożenie profesji nie było jeszcze całkowitym włączeniem kandydata do wspólnoty. Znajdują się tu celebracje które sprawowano na trzeci dzień po profesji, a zostały przedstawione w rozdziale V tej części (Modus recipiendi ad

58 Ceremonial, s. 34-36.

59 Sz. Hiżycki, Kiedy mnisi zaczęli siedzieć w celi? „Cenobium” 23 (2016), s. 38.

${ }^{60}$ Ceremonial, s. 36-37.

${ }^{61}$ M.Y. MacDonald, List do Efezjan, w: W.R. Farmer (red.), Międzynarodowy komentarz do Pisma Świętego, Warszawa 2001, s. 1528.

${ }^{62}$ B. Happle, Die Profeßordnung des 58. Kapitels der Benediktinerregel, BM 31 (1955), s. 108.

${ }^{63}$ Ceremoniał, s. 37-38.

${ }^{64}$ M. Rothenhäusler, Die Anfänge der klösterlichen Profess, BM 4 (1922), s. 28. 
Communitatem Neo Professum die Tertia a Professione). Rozporządzenia dotyczące tego zwyczaju zostały przyjęte w 1751 roku przez Kongregację. Nakazano wówczas, aby przez trzy kolejne dni neoprofes przyjmował Komunię św., a do formularza mszalnego dodawano własne modlitwy w jego intencji ${ }^{65}$.

Podczas trzech dni przed definitywnym włączeniem do wspólnoty neoprofes miał zachować szczególne skupienie. Trzeciego dnia neoprofes po przyjęciu Komunii św. klękał pośrodku zgromadzonej wspólnoty, a przełożony po odczytaniu fragmentu reguły zdejmował $\mathrm{z}$ jego głowy kaptur kreśląc nad nim znak krzyża. Recytował wówczas po wersetach Adiutorium nostrum... modlitwę: Domine Iesu Christe, totius sanctae Religionis origo... Słowami tej modlitwy prosił, aby Chrystus przyjął łaskawie śluby swego sługi. Jak jego zakryta głowa podczas trzech dni oznaczała mistyczne osłonięcie, tak błagano Pana, aby neoprofes uwolniony od przyjemności światowych został ukrzyżowany dla tego świata, dniami i nocami służył Bogu. Ponadto miał pielęgnować niewinność i skromność serca, przestrzegał postów oraz zawsze starał się zachowywać postawę miłości wobec innych. Na koniec prosił, aby ten, który został powołany do monasteru otrzymał łaskę, aby zawsze umiłował ciasną bramę i stromą drogę, i nią tylko podążał do wiecznej chwały ${ }^{66}$.

Po odmówieniu modlitwy przełożony pouczał neoprofesa, w jaki sposób ma postępować $\mathrm{w}$ życiu zakonnym. Wszystkie przepisy prawa miał wypełniać $\mathrm{z}$ tego względu, że czeka na niego wielka nagroda $\mathrm{w}$ niebie, aby podobać się Chrystusowi - oblubieńcowi swej duszy, który będąc na równi z Bogiem stał się posłusznym aż do śmierci (por. Flp 2,6-8). Na koniec upominał profesa, aby zachowywał tajemnicę wynikającą z uczestnictwa w kapitułach ${ }^{67}$. Święty Benedykt przewidział możliwość, że gdyby któryś za podszeptem szatana chciałby wystąpić z zakonu, jego świeckie ubranie miało być przechowywane w westiarni. Odchodząc, nie mógł jednak odzyskać swojej karty profesji ${ }^{68}$.

65 Ceremoniał, s. 20.

66 Ceremoniał, s. 39-42.

67 Ceremoniał, s. $42-45$.

68 Reguła 58, 27-29. 


\section{PODSUMOWANIE}

Celebracje związane z przyjmowaniem braci oraz złożeniem profesji mniszej zostały przedłożone w ceremoniale tynieckim z XVIII wieku. Celebracje te dotyczyły przyjęcia kandydatów do monasteru, obrzędów sprawowanych przed przyjęciem do nowicjatu, obrzędów profesji uroczystej oraz włączenia do pełnej wspólnoty z braćmi po profesji. Św. Benedykt w swojej regule pozostawił istotne wskazania co do przyjmowania braci i złożenia profesji monastycznej, które od VIII wieku zostały rozbudowane o liczne modlitwy gesty i celebracje liturgiczne.

Według reguły św. Benedykta śluby zakonne składano w oratorium, ale wyraźnie nie zapisano, że miało to miejsce podczas Mszy św. Zgodnie $\mathrm{z}$ ceremoniałem tynieckim śluby składano zawsze podczas Mszy św. Istotnym elementem złożenia profesji zakonnej było odczytanie dokumentu z rotą przysięgi, podpisanie go znakiem krzyża oraz złożenie na ołtarzu. O tak dokładnych rozporządzeniach nie wspominał św. Benedykt. Szaty świeckie pozostawiano w westiarni, gdyby kandydat chciał opuścić klasztor. Podczas składania profesji zakonnej, zapisanej w regule św. Benedykta, znakiem oddania był śpiew wersetu: „Przyjmij mnie, Panie, według Twej obietnicy, a żyć będę. I nie zawiedź nadziei mojej” (Ps 119 [118],116). Zarówno sam śpiew, jak też towarzyszące mu gesty miały podkreślić oddanie kandydata Bogu, a z drugiej strony uznania go za swego syna na płaszczyźnie dzięcięctwa Bożego.

Święty Benedykt wskazania dotyczące przyjmowania braci zapisał w 58 rozdziale w 29 wierszach, ale zostały one ubogacone o liczne zwyczaje i modlitwy, które w ceremoniale tynieckim zamieszczono w ośmiu rozdziałach. Wprawdzie ceremoniał ten był używany do zniesienia Kongregacji w 1864 r., ale stanowi cenne źródło poznania liturgii benedyktynów w Polsce w XVIII i na początku XIX wieku. 


\section{BIBLIOGRAFIA}

Św. Benedykt z Nursji, Reguła, Tyniec 1994.

Boguniowski J. W., Rozwój historyczny ksiag liturgii rzymskiej do Soboru Trydenckiego i ich recepcja $w$ Polsce, Kraków 2001.

Casel O., Mönchtum und Pneuma, w: P. Krüger, J. Tyciak (Hrsg.), Morgenländisches Christentum. Wege zu einer ökumenischen Theologie, Paderborn 1940/44, s. 228-246.

Coeremoniale Monasticum pro Inclyta Congregatione Benedictino-Polona Sub Titulo SS. Crucis Accommodatum, Jussu \& Auctoritate Capituli Generalis In Monasterio Tynecensi Celebrati Editum, Omnibus vero Monasteriis dictae Congregationis Pro Methodo In Ecclesiasticis, et Monasticis functionibus, servanda porrectum, Anno Quo, per Verbum Incarnatum facta est. haeC MVtatIo DeXterae eXCeLsI. Psal: 76. v. 10. Calissii, Typis Sacrae Regiae Majestatis et Rei-Publicae.

Congar Y., Wierzę w Ducha Świętego, t. I, Warszawa 1995.

Estreicher K., Bibliografia Polska, t. 20, Kraków 1905.

Happle B., Die Profeßordnung des 58. Kapitels der Benediktinerregel, BM 31 (1955), s. 9-22, 101-116.

Hiżycki Sz., Kiedy mnisi zaczęli siedzieć w celi? „Cenobium” 23 (2016), s. 25-39.

Jüngling H.-W., Księga Psalmów, w: W.R. Farmer (red.), Międzynarodowy komentarz do Pisma Świętego, Warszawa 2001, s. 692-765.

Kanior M., Polska kongregacja benedyktyńska św. Krzyża 1709-1864, Kraków 2000.

Krakowiak Cz., Tonsura, EK 19, kol. 891-892.

Leclerq J., Pochwała statości, „Cenobium” 23 (2016), s. 11-24.

MacDonald M. Y., List do Efezjan, w: W. R. Farmer (red.), Międzynarodowy komentarz do Pisma Świętego, Warszawa 2001, s. 1515-1529.

Martimort A.G., Handbuch der Liturgiewissenschaft, t. II, Freiburg im Breisgau 1965.

Nadolski B., Liturgika, t. III, Poznań 1992.

Puzicha M., Kommentar zur Benediktusregel, St. Ottilien 2002.

Rollin B., Jak żyć dzisiaj Reguła św. Benedykta. Komentarz do Reguty, Kraków 2005.

Rothenhäusler M., Die Anfänge der klösterlichen Profess, BM 4 (1922), s. 21-28.

Rothenhäusler M., Unter dem Geheimnis des Kreuzes. Die klösterliche Profess bei Kassian, BM 5 (1923), s. 91-96.

Sczaniecki P., Benedyktyni, w: Zakony benedyktyńskie w Polsce. Krótka historia, Tyniec 1981, s. 39-77.

Straszewicz M., Veni, creator Spiritus, EK 20, kol. 42-43.

de Vogüé A., Jak formować do stałości? „Cenobium” 23 (2016), s. 77-86.

de Vogüé A., La comunità ordinamento e spiritualità, Praglia 1991.

Zatorski W., Stałość w „Regule” św. Benedykta, „Cenobium” 23 (2016), s. 41-49. 